\title{
Letter
}

\section{Revealing the surge behaviour of the Yangtze River headwater glacier during 1989-2015 with TanDEM-X and Landsat images}

Mountain glaciers are the most important headwater source for rivers on the Tibetan Plateau. The Yangtze River has a length of $6380 \mathrm{~km}$; it is the longest river in China and the thirdlongest in the world. It has a basin area of $180 \times 10^{4} \mathrm{~km}^{2}$, and its annual runoff capacity is over $1 / 3$ of the total budget of the country (Jiang and Wang, 2004; Dai and Yang, 2006). The river originates from the middle region of the Tanggula Mountain Range on the Qinghai-Tibetan Plateau (Fig. 1), which has an average elevation of more than $5000 \mathrm{~m}$ and more than 100 glaciers. The Jianggudiru Glacier serves as the headwater glacier of the Yangtze River and is located southwest of Geladandong Peak (Fig. 1). It is horseshoeshaped and has two tributaries extending northward and southward. The southern and northern Jianggudiru Glaciers (SJG and NJG) have areas of $\sim 32$ and $26 \mathrm{~km}^{2}$, respectively. The SJG and NJG are located on the Tibetan Plateau with limited influence from the monsoonal and westerlies, but are affected by the strong local circulation (Wang and others, 2013). The accumulation season is from May to September (Ye and others, 2006). Because of the remoteness and very high altitude of the Jianggudiru Glacier, there has been little fieldwork on monitoring its changes, and understanding of this glacier is limited.

Space-borne Earth observation techniques have been used to study glaciers because of their ability to monitor regions of interest periodically and objectively at a low budget. The Landsat series satellites with the Multispectral Scanner (MSS), Thematic Mapper (TM), Enhanced Thematic Mapper Plus (ETM+) and Operational Land Imager (OLI) sensors and satellites with synthetic aperture radar (SAR) sensors provide useful data for most studies on glacier changes. In the present study, the DLR TerraSAR-X add-on for Digital Elevation Measurement (TanDEM-X) and Landsat images were combined to reveal the surge behaviour of both SJG and NJG for the first time.

Previous studies on the Geladandong mountain glaciers were always based on the a priori assumption that the glacier change in this area is slow and controlled by climate change (Ye and others, 2006; Zhang and others, 2008), so quick short-term changes in the glacier have always been missed. Lu and others (2002) studied the Geladandong region for variations in the glacier area between 1969 and 2000 by using aerial photos and Landsat TM images. Their results indicated that the glacier area had decreased by $\sim 1.7 \%$ from 1969 to 2000, while the SJG had retreated more than $1 \mathrm{~km}$ over those 31 years. Ye and others (2006) analysed the Geladandong Glacier area change during 1969-76 and 1992-2002 with Landsat MSS, TM and ETM+ images. Their results showed an accelerated glacier retreat that likely increased due to the summer air temperature in this area. Zhang and othes (2008) studied the Geladandong Glacier area change over the periods of 1968-71 and 2001/02 using the Chinese Glacier inventory and Landsat ETM+ images. They analysed four glaciers, including the NJG and SJG. The four glaciers all displayed a retreating trend during the study period, which contradicts Lu et al.'s study (2002) of Glacier 5K451F0012 (GLIMS ID G091050E33584N). Zhang and others (2008) noted that this may have been caused by a glacier surge that is independent of climate change in this region. SAR data were recently used to study the Geladandong Glacier. Velocity maps were obtained for the years 1996-2010 and the NJG was identified as a surge-type glacier with SAR intensity offset tracking. Meanwhile acceptable results for the SJG were not obtained (Li and others, 2014).

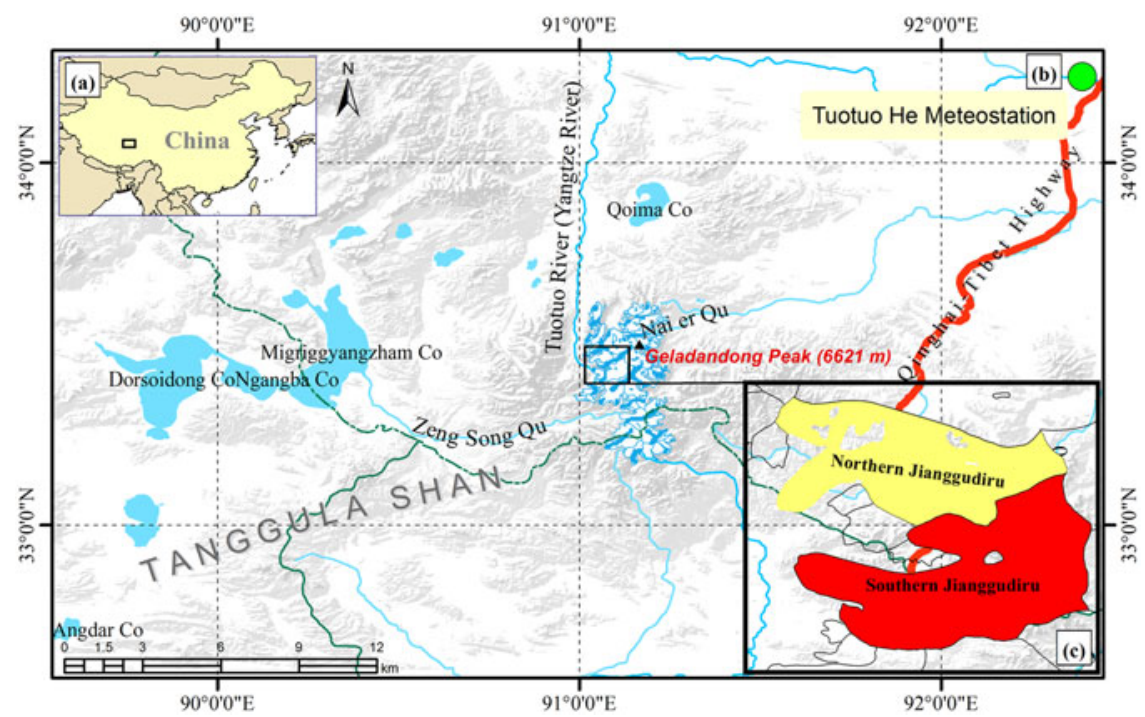

Fig. 1. (a) Location of the studied area in West China, which is marked with a black rectangle. (b) Location of the Geladandong Mountain and the glaciers around the peak; the background is the shaded relief from the SRTM DEM, the blue regions are lakes, and the blue lines are rivers. (c) Location of the Jianggudiru Glacier; the yellow area is the Northern Jianggudiru Glacier, and the red area is the Southern Jianggudiru Glacier. 
Glacier surging is a phenomenon that reflects internal dynamic changes rather than influence from the climate (Meier and Post, 1969; Raymond, 1987). Although surging glaciers only make up $\sim 1 \%$ of the global glacier population, they have an important role in the investigation of glacier processes (Kamb and others, 1985; Clarke, 1987; Jiskoot and others, 2000; Sevestre and Benn, 2015). A surging glacier displays a multiyear and quasi-periodic oscillating behaviour between two phases: a long quiescent phase up to tens or hundred years and a short-term fast-moving phase that may last several years. The cycle occurs repeatedly (Kamb and others, 1985; Raymond, 1987). Surging glaciers have various dynamical and morphological characteristics, such as a rapidly advancing ice front, thickened terminus and thinning in the accumulation area during the surging period (Meier and Post, 1969; Clarke, 1987; Lv and others, 2016). Such behaviour has been used to identify surging glaciers around the world (Murray and others, 1998; Copland and others, 2003; Hewitt, 2007; Jiskoot and Juhlin, 2009; Burgess and others, 2012; Pitte and others, 2016).

During a glacier surge, a large volume of ice is transferred rapidly from the up-valley reservoir area to a down-glacier receiving area, and a large elevation change occurs in the reservoir and receiving areas (Meier and Post, 1969; Murray and others, 1998; Pitte and others, 2016). This causes obvious geometric changes in the glaciers. If this signal can be observed, then surging behaviour can be identified. The DEM difference method was used to study the geometric changes in the headwater glacier of the Yangtze River. The DEM difference method efficiently extracts the temporal surface elevation change of the glacier and has been used in many studies on normal glacier changes (Kargel and others, 2005; Surazakov and Aizen, 2006; Paul and Haeberli, 2008; Kronenberg and others, 2016) and elevation changes of surging glaciers (Auriac and others, 2014; Pitte and others, 2016; King and others, 2016).

To quantify the glacier elevation changes, images from the Shuttle Radar Topography Mission (SRTM) DEM of USGS, Advanced Spaceborne Thermal Emission and Reflection Radiometer (ASTER) DEM processed by USGS, and TanDEM-X images from the DLR were collected. SRTM Cband SAR images were acquired in February 2000, and a total of nine ASTER images spanning from 2001 to 2015 with less cloud cover were used to generate DEMs with the help of USGS. The quality of the final DEMs was checked with the SRTM DEM; only one ASTER DEM acquired on 4
May 2007 was usable for the Jianggudiru Glacier, which has a std dev $<7 \mathrm{~m}$ for the off-glacier area between SRTM and ASTER DEM. The TanDEM-X images were acquired on 3 April 2014 with $\mathrm{HH}$ polarisation in the stripmap mode. The baseline is an important parameter during the InSAR processing (Krieger and others, 2007; Liu and others, 2016), especially for the TanDEM-X InSAR processing. A baseline error of $\sim 1 \mathrm{~mm}$ would cause a height error of $\sim 4 \mathrm{~m}$ for this TanDEM-X image pair. The baseline-induced phase error was adjusted first to improve the height accuracy obtained from the TanDEM-X images (González and others, 2012) and the relative theoretical vertical accuracy was 2-4 m depending on the slope (Krieger and others, 2007). The vertical accuracy was estimated to be $<4.5 \mathrm{~m}$ of the DEM difference between TanDEM-X and SRTM DEM from the offglacier area. Another issue which should be mentioned is that the DEMs obtained from $C$ and $X$ band SAR have small differences due to their different penetration depths, while the ASTER DEM, based on visible wavelength, represents the true surface. These considerations are important when interpreting smaller changes on glacier surfaces.

The DEM difference results show that the down-glacier elevation changes of the NJG between 2000 and 2014 showed a thickening of up to $60 \mathrm{~m}$ (Fig. 2a), while the elevation changes between 2007 and 2014 showed thinning of $\sim 30 \mathrm{~m}$ (Fig. 2b). This means that the down-glacier elevation of the NJG reached a maximum $(>90 \mathrm{~m})$ sometime after 2000 but before 2007 - possibly due to glacier surging and then dropped down continuously until 2014. In contrast, the elevation of the up valley glacier of the NJG between 2000 and 2014 showed thinning of $\sim 20 \mathrm{~m}$ (Fig. 2a), while the elevation changes between 2007 and 2014 showed thickening of more than $10 \mathrm{~m}$ (Fig. 2b).

In contrast, the elevation change of the SJG was different. In the upper reaches, the SJG thickened by up to $10 \mathrm{~m}$ between 2000 and 2014 (Fig. 2a), while the elevation changes between 2007 and 2014 showed thinning of $\sim 10$ $\mathrm{m}$ (Fig. 2b). The rate of change in the upper elevation was clearly less than that of the NJG. The down-glacier elevation of the SJG dropped continuously between 2000 and 2014 by up to $50 \mathrm{~m}$, while the difference decreased to $30 \mathrm{~m}$ between 2007 and 2014. The down-glacier elevation change of the SJG hints that there may have been a surging event before 2000 that caused a big down-glacier elevation rise of the SJG and that the elevation then dropped after the surge.

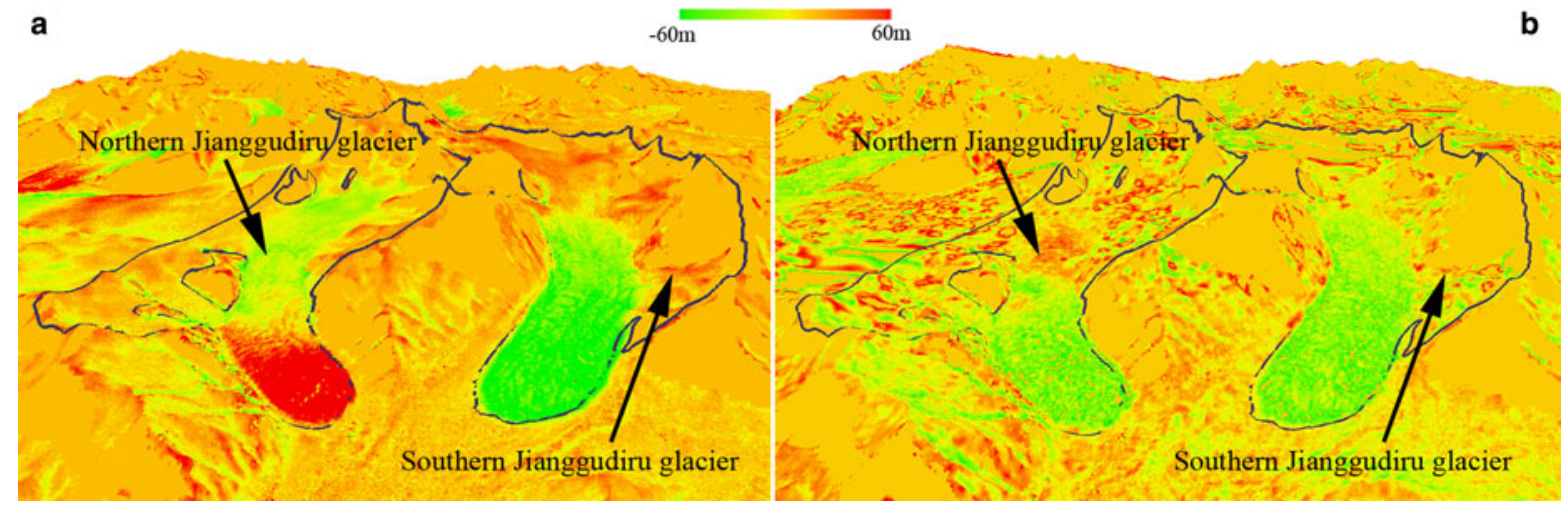

Fig. 2. DEM difference results for the Jianggudiru Glacier. The layover and shadow area were assigned to zero: (a) Elevation change between February 2000 (SRTM DEM) and May 2014 (TanDEM-X DEM); (b) Elevation change between April 2007 (ASTER DEM) and May 2014 (TanDEM-X DEM). 

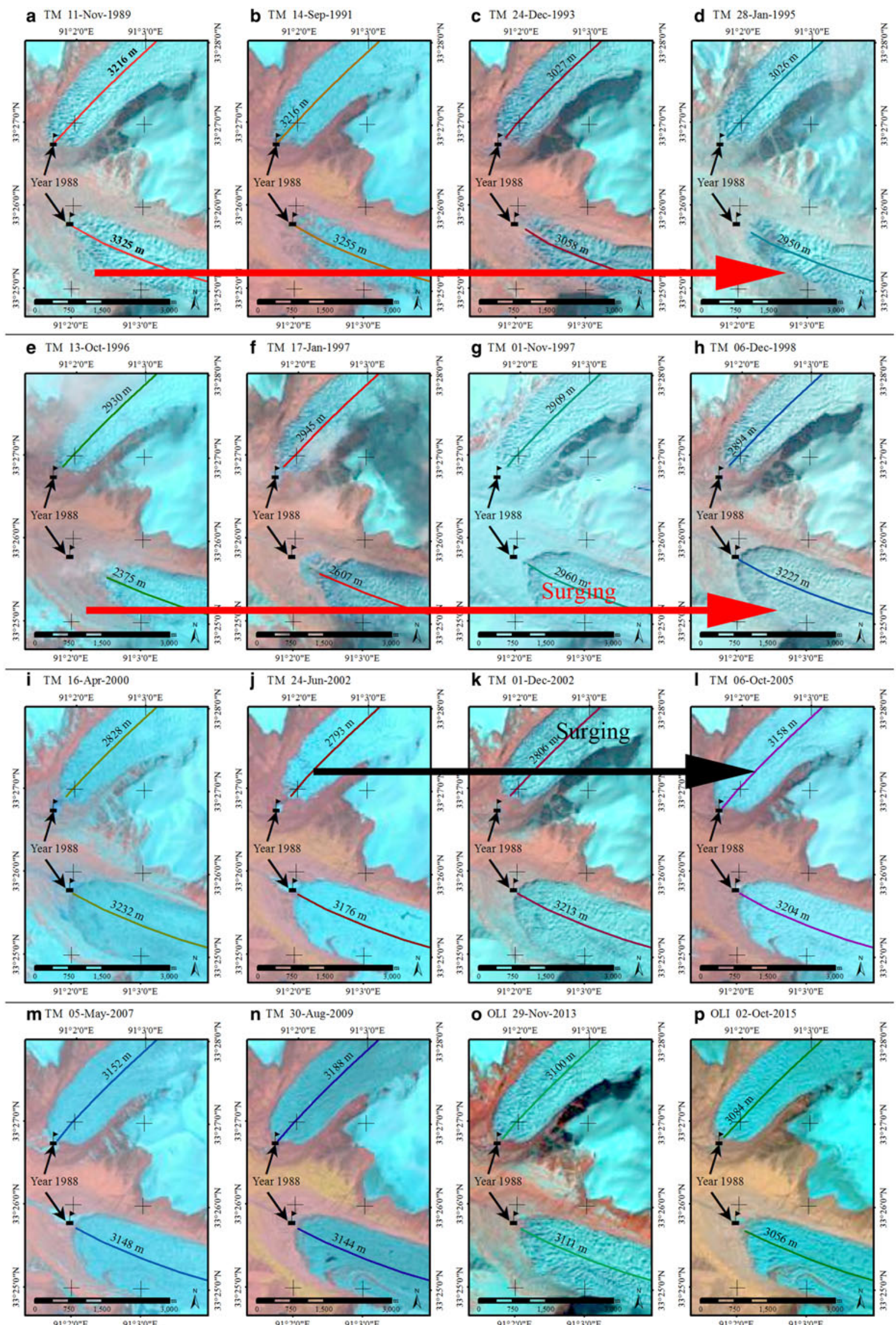

Fig. 3. Down-glacier Landsat images of the NJG and SJG with the length tagged (NJG: from top border to the terminus, SJG: from right border to the terminus). (a)-(p) correspond with different years and dates of the Landsat images. The flag corresponds with the terminus position in 1988, the accuracy of glacier margin position is $\sim \pm 42 \mathrm{~m}$ and $\pm 21 \mathrm{~m}$ separately for TM and OLI images (Williams and others, 1997). 
Because there have been no previous studies on the surging phenomena of the headwater glacier in this area, the results from the previous DEM differencing method were examined according to changes in the time-series Landsat TM images from 1988 to 2015 in order to realise a more comprehensive understanding of the glacier change behaviour.

For the SJG, the down-glacier changes could be divided into four different periods. In Figure 3, the first row of TM images shows that, before 1996, the SJG was continuously retreating, and the SJG terminus retreated $\sim 1 \mathrm{~km}$ during 1989-96 (Figs 3a-e). From 1996, the glacier began to advance rapidly; it moved forward more than $1 \mathrm{~km}$ within 2 years (red arrow in Figs 3e-h). The position and shape of the SJG terminus were relatively stable from 2000 to 2006 (Figs 3i-I). From 2007 to the present, there has been a narrowing trend for the transverse section, and the terminus position has been slowly retreating (Figs 3m-p). This corresponds with the DEM difference results showing that the down-glacier elevation of the SJG has continued to drop after the surge event in 2000. Furthermore, there has been little change in the down-glacier shape of the SJG (Figs 3i-I).

The NJG showed different behaviour compared with the SJG. The position of the terminus was relatively stable from 1988 to 1996 (Figs 3a-e). Then the position of the terminus began to retreat slowly up to 2002 (Figs 3e-j). From 2002, the glacier rapidly advanced more than $500 \mathrm{~m}$ until 2005 (black arrow in Figs 3j-I). Similar to the changes in the SJG, the transverse section has narrowed since 2007, and the terminus position of the NJG has slowly retreated since then to the present (Figs $3 \mathrm{~m}-\mathrm{p}$ ). These results are consistent with the DEM differencing results. The down-glacier elevation of the NJG increased more than $90 \mathrm{~m}$ since 2002 after surging up to 2005 and then has been dropping from 2006 until now.

Although it has been suggested that an environmental control is not obvious for glacier surging (Meier and Post, 1969; Raymond, 1987), climate change may be a possible reason for changes in surging behaviour. For example, it may lead to a change in the number, amplitude, period and mechanism of surging glaciers (Hoinkes, 1969; Copland and others, 2011; Flowers and others, 2011; Sevestre and Benn, 2015).
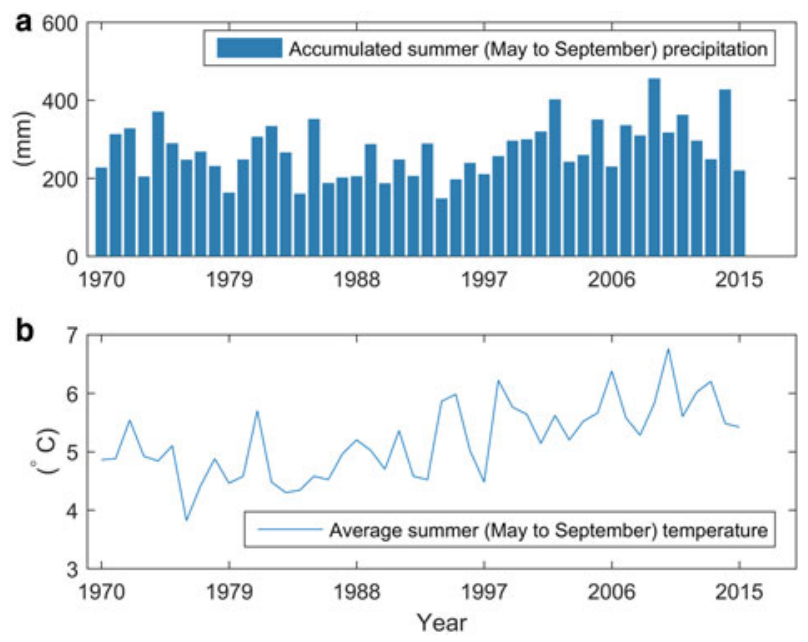

Fig. 4. Meteorological data of the Tuotuohe station from the China Meteorological Administration. (a) Accumulated summer (MaySeptember) precipitation (mm). (b) Average summer (MaySeptember) temperature $\left({ }^{\circ} \mathrm{C}\right)$.
Accumulated summer (May-September) precipitation (Fig. 4a) at Tuotuohe station has no clear trend with a mean value $\sim 235 \mathrm{~mm}$ from 1970 to 2015, while the time-series plot of the average summer (May-September) temperature showed a rising trend especially from 1990 to 2010 (Fig. 4b). This region is located within a well-defined climatic envelope of $0-10^{\circ} \mathrm{C}$ for the mean summer temperature and 200-2250 $\mathrm{mm}$ for the mean summer precipitation, and glaciers appear to be more prone to surging under this climate (Sevestre and Benn, 2015). However, the glacier surges were not synchronised with the meteorological change, and the SJG and NJG were not changing together even though they are very close to each other. Thus, the internal surge mechanism in each glacier dominates its behaviour over this time period.

We used a combination of three different types of DEMs, and a series of Landsat images to reveal the surge behaviour of the Yangtze River headwater glacier. The SJG surged 1997, while the NJG surged 2002. Our analysis takes advantage of both the DEM differencing, and sequential Landsat images to discover both the elevation and area changes of a previously unknown surging glacier. This method, in particular due to global repeat coverage of TanDEM-X in recent years, provides a quickway to discover not yet identified glacier surges in other regions of the world.

\section{ACKNOWLEDGEMENTS}

This research was supported by the National Natural Science Foundation of China [Grant numbers 41590852, 41120114001, 41001264]; Natural Science Foundation of Jiangsu Province [Grant no. BK20150189]; The TanDEM-X data acquisition has been supported by the DLR AO project [Grant no. GEOL6996, GEOL0447]; The SRTM DEM, ASTER and Landsat images were downloaded from http://glovis.usgs.gov. We greatly appreciate the anonymous reviewers for their constructive comments. We thank Chief Editor Graham Cogley, Associate Chief Editor Hester Jiskoot, Scientific Editor David Rippin and Mrs Lynsey Rowland for comments and helping improve the manuscript.

${ }^{1}$ Key Laboratory of Digital Earth GUANG LIU ${ }^{1}$ Science, Institute of Remote Sensing and Digital Earth, Chinese Academy of Sciences, Beijing, China, ${ }^{2}$ Jiangsu Key Laboratory of Resources and Environmental Engineering, School of Environment Science and Spatial Informatics, China University of Mining and Technology, Xuzhou, China, ${ }^{3}$ Forschungszentrum Jülich $\mathrm{GmbH}$, Institute of Energy and Climate Research, Stratosphere (IEK-7), Jülich, Germany, ${ }^{4}$ School of Earth Sciences and Engineering, Nanjing University, Nanjing, China

E-mail: Guang Liu <liuguang@radi.ac.cn>

\section{REFERENCES}

Auriac A and 7 others (2014) InSAR observations and models of crustal deformation due to a glacial surge in Iceland. Geophys. J. Int., 198(3), 1329-1341 (doi: 10.1093/gji/ggu205) 
Burgess EW, Forster RR, Larsen CF and Braun M (2012) Surge dynamics on Bering Glacier, Alaska, in 2008-2011. Cryosph., 6(6), 1251-1262 (doi: 10.5194/tc-6-1251-2012)

Clarke GKC (1987) Fast glacier flow: ice streams, surging, and tidewater glaciers. J. Geophys. Res., 92(B9), 8835 (doi: 10.1029/ JB092iB09p08835)

Copland L, Sharp MJ and Dowdeswell JA (2003) The distribution and flow characteristics of surge-type glaciers in the Canadian High Arctic. Ann. Glaciol., 36, 73-81 (doi: 10.3189/ 172756403781816301)

Copland L and 7 others (2011) Expanded and recently increased glacier surging in the Karakoram. Arctic, Antarct. Alp. Res., 43 (4), 503-516 (doi: 10.1657/1938-4246-43.4.503)

Dai S and Yang S (2006) Variations in water resources of the Yangtze River over the last five decades. J. Nat. Resour., 21(4), 501-506

Flowers GE, Roux N, Pimentel S and Schoof CG (2011) Present dynamics and future prognosis of a slowly surging glacier. Cryosphere, 5(1), 299-313 (doi: 10.5194/tc-5-299-2011)

González JH and 6 others (2012) Bistatic system and baseline calibration in TanDEM-X to ensure the global digital elevation model quality. \{ISPRS\} J. Photogramm. Remote Sens., 73, 3-11 (doi: http://dx.doi.org/10.1016/j.isprsjprs.2012.05.008)

Hewitt K (2007) Tributary glacier surges an exceptional concentration at Panmah Glacier, Karakoram Himalaya. J. Glaciol., 53 (181), 181-188 (doi: 10.3189/172756507782202829)

Hoinkes HC (1969) Surges of the Vernagtferner in the Ötztal Alps since 1599. Can. J. Earth Sci., 6(4), 853-861 (doi: 10.1139/ e69-086)

Jiang J and Wang S (2004) Primary analyse of water resource, disasters and environment in the changjiang river catchment. Quat. Sci., 24(5), 512-517 (doi: 1001-7410(2004)05-512-06)

Jiskoot $\mathrm{H}$ and Juhlin DT (2009) Surge of a small East Greenland glacier, 2001-2007, suggests Svalbard-type surge mechanism. J. Glaciol., 55(191), 567-570

Jiskoot H, Murray T and Boyle P (2000) Controls on the distribution of surge-type glaciers in Svalbard. J. Glaciol., 46(154), 412-422 (doi: 10.3189/172756500781833115)

Kamb B and 7 others (1985) Glacier surge mechanism: 1982-1983 surge of variegated glacier, Alaska. Science, 227(4686), 469-479 (doi: 10.1126/science.227.4686.469)

Kargel JS and 16 others (2005) Multispectral imaging contributions to global land ice measurements from space. Remote Sens. Environ., 99(1-2), 187-219 (doi: http://dx.doi.org/10.1016/j.rse. 2005.07.004)

King O, Hambrey MJ, Irvine-Fynn TDL and Holt TO (2016) The structural, geometric and volumetric changes of a polythermal Arctic glacier during a surge cycle: Comfortlessbreen, Svalbard. Earth Surf. Process. Landf., 41(2), 162-177 (doi: 10.1002/ esp.3796)

Krieger G and 6 others (2007) TanDEM-X: a satellite formation for high-resolution SAR interferometry. IEEE Trans. Geosci. Remote Sens., 45(11), 3317-3341 (doi: 10.1109/TGRS.2007.900693)

Kronenberg $M$ and 9 others (2016) Mass-balance reconstruction for Glacier No. 354, Tien Shan, from 2003 to 2014. Ann. Glaciol., 57(71), 92-102 (doi: 10.3189/2016AoG71A032)
Li G, Lin H, Li Y, Zhang H and Jiang L (2014) Monitoring glacier flow rates dynamic of Geladandong Ice Field by SAR images Interferometry and offset tracking. 2014 IEEE Geoscience and Remote Sensing Symp. 4022-4025 (doi: 10.1109/ IGARSS.2014.6947368)

Liu G, Hanssen RF, Guo H, Yue H and Perski Z (2016) Nonlinear Model for InSAR Baseline Error. IEEE Trans. Geosci. Remote Sens., 54(9), 5341-5351 (doi: 10.1109/TGRS.2016.2561305)

Lu A, Yao T, Liu S, Ding L and Li G (2002) Glacier change in the Geladandong Area of the Tibetan Plateau monitored by remote sSensing. J. Glaciol. Geocryol., 24(5), 559-562 (doi: 10.3969/j. issn.1000-0240.2002.05.014)

Lv M and 7 others (2016) A rapid glacier surge on Mount Tobe Feng, western China, 2015. J. Glaciol., 62(232), 407-409 (doi: http:// dx.doi.org/10.1017/jog.2016.42)

Meier MF and Post A (1969) What are glacier surges? Can. J. Earth Sci., 6(4), 807-817 (doi: 10.1139/e69-081)

Murray T, Dowdeswell JA, Drewry DJ and Frearson I (1998) Geometric evolution and ice dynamics during a surge of Bakaninbreen, Svalbard. J. Glaciol., 44(147), 263-272 (doi: http://dx.doi.org/10.3198/1998JoG44-147-263-272)

Paul F and Haeberli W (2008) Spatial variability of glacier elevation changes in the Swiss Alps obtained from two digital elevation models. Geophys. Res. Lett., 35(21), L21502 (doi: 10.1029/ 2008GL034718)

Pitte P and 7 others (2016) Geometric evolution of the Horcones Inferior Glacier (Mount Aconcagua, Central Andes) during the 2002-2006 surge. J. Geophys. Res. Earth Surf., 121(1), 111127 (doi: 10.1002/2015JF003522)

Raymond CF (1987) How do glaciers surge? A review. J. Geophys. Res. Solid Earth, 92(B9), 9121-9134 (doi: 10.1029/JB092iB09p09121)

Sevestre H and Benn DI (2015) Climatic and geometric controls on the global distribution of surge-type glaciers - University of St. Andrews. J. Glaciol., 61(228), 646-662 (doi: 10.3189/ 2015JoG14J136)

Surazakov AB and Aizen VB (2006) Estimating volume change of mountain glaciers using SRTM and map-based topographic data. IEEE Trans. Geosci. Remote Sens., 44(10), 2991-2995 (doi: 10.1109/TGRS.2006.875357)

Wang Y, WU L and Liu S (2013) Variation and uncertainty analysis of the glaciers in the past 50 years in Geladandong of Tibetan Plateau. J. Glaciol. Geocryol., 35(2), 255-262 (doi: 10.7522/j. issn.1000-0240.2013.0031)

Williams RS, Jr., Hall DK, Sigurdsson O and Chien JYL (1997) Comparison of satellite-derived with ground-based measurements of the fluctuations of the margins of Vatnajokull, Iceland, 1973-92. Ann. Glaciol., 24, 72-80

Ye Q, Kang S, Chen F and Wang J (2006) Monitoring glacier variations on Geladandong mountain, central Tibetan Plateau, from 1969 to 2002 using remote-sensing and GIS technologies. J. Glaciol., 52 (179), 537-545 (doi: 10.3189/172756506781828359)

Zhang Y, Liu S, Xu J and Shangguan D (2008) Glacier change and glacier runoff variation in the Tuotuo River basin, the source region of Yangtze River in western China. Environ. Geol., 56 (1), 59-68 (doi: 10.1007/s00254-007-1139-2) 